\title{
Seasonal Assessment of Some Water Quality Parameters for Estuarine and Riverine Zones of Narmada River, Gujarat
}

\author{
Ronak Gupta $^{1}$, Ketan Tatu ${ }^{2}$, Lamb Christian $^{3} *$ Darpak Joshi $^{4}$, R.D. Kamboj ${ }^{5}$ \\ 1,2,3,4,5 Gujarat Ecological Education and Research (GEER) Foundation, Gandhinagar, India \\ *Corresponding Author: 1j.j11517@gmail.com , Tel.: +918460780835
}

Available online at: www.isroset.org

Received: 05/Oct/2018, Accepted: 22/Oct/2018, Online: 31/Oct/2018

\begin{abstract}
The present study was carried out at eatuarine and riverine regions of river Narmada, one of the four major rivers of Gujarat. A total of eleven physico-chemical parameters of water were analyzed seasonally during a period of February 2017 to September 2017. The range of physical and chemical parameters obtained are Temperature $21.0^{\circ} \mathrm{C}$ to $36.90^{\circ} \mathrm{C}$, Turbidity 0.04 NTU to $923 \mathrm{NTU}, \mathrm{pH} 7.2$ to 9.0 , Electrical Conductivity $0.0018 \mathrm{mS}$ to $40.78 \mathrm{mS}$, Total Dissolved Solids $0.9 \mathrm{ppt}$ to $5209 \mathrm{ppt}$, Dissolve Oxygen $3.42 \mathrm{mg} / \mathrm{l}$ to $8.32 \mathrm{mg} / \mathrm{l}$, Salinity $0.27 \mathrm{ppt}$ to $56.08 \mathrm{ppt}$, Acidity $30 \mathrm{mg} / \mathrm{l}$ as $\mathrm{CaCO}_{3}$ to $90 \mathrm{mg} / \mathrm{l}$ as $\mathrm{CaCO}_{3}$, Alkalinity $40 \mathrm{mg} / \mathrm{l}$ as $\mathrm{CaCO}_{3}$ to $200 \mathrm{mg} / \mathrm{l}$ as $\mathrm{CaCO}_{3}$ and Total Hardness $600 \mathrm{mg} / \mathrm{l}$ as $\mathrm{CaCO}_{3}$ to $16000 \mathrm{mg} / \mathrm{l}$ as $\mathrm{CaCO}_{3} \mathrm{The}$ results of present research work revealed that certain parameters such as Total Hardness, Turbidity, and Total Dissolved Solids were not found to be within the acceptable range of IS 10500 - 2004 from the view point of domestic purpose; which might be due to the point and non-point sources of pollution that the river receives mainly by means of industrial effluent, agricultural runoff, and domestic sewage. Further, the water quality data generated from this study will help in potential remediation and other management decisions.
\end{abstract}

Keywords: Estuarine Zone, Narmada, Physico-Chemical parameters, Riverine Zone, Seasonal sampling, Water quality

\section{INTRODUCTION}

Estuaries are important component of the coastal ecosystems [1]. They are called "nurseries of the sea" because they provide food and habitat to various organisms. Estuaries provide a wide range of habitats leading to a great diversity of marine life ranging from microscopic plankton to some large animals like Whale shark, Blue whale and Dugong [2]. They act as a buffer zone between the ocean and the land. They are important for the health of the oceans as they filter sediment and pollutants from the water before they flow into the oceans. Estuaries are socio - economically important in terms of coastal activities of society as they are used for recreational fishing, boating, and tourism. Unfortunately, the increased human interferences have been degrading the quality of these vital ecosystems [3]. Water quality of estuaries and their contiguous river-stretches are often badly affected by a variety of human activities. Therefore, it is essential to monitor their water quality on seasonal bases. Gujarat Ecological Education and Research (GEER) Foundation has been monitoring water quality of Narmada estuary from 2016 under a scheme assigned by Forests and Environment Department, Gujarat State. The present paper is based on GEER Foundation's monitoring activity that was carried out from February 2017 to September 2017

Many researchers have worked on the estuaries of India and Gujarat. Sharmaet al.2011have studied physico-chemical parameters of the Narmada river in Madhya Pradesh. Deshkaret al.2012 have studied water quality of three estuaries of Gujarat viz. Sabarmati, Mahi and Narmada. Nirmal Kumaret al. (2012) have conducted studies on the physic-chemical parameters and statistical evaluation of the Narmada estuary. George (2012) has worked on the biotic components and their relation with nutrients of some selected sites of Narmada estuary. However, there have been no studies in the recent time-frame based on seasonal water quality monitoring of Narmada estuary and some riverine (freshwater) stretch contiguous with it. The present study has attempted to fill up this scientific gap.

Section I of the paper contains brief introduction about the topic, Section II contain the study area and methodology used, Section III elaborates results and discussion and Section IV concludes research work with some recommendations. 


\section{STUDY AREA}

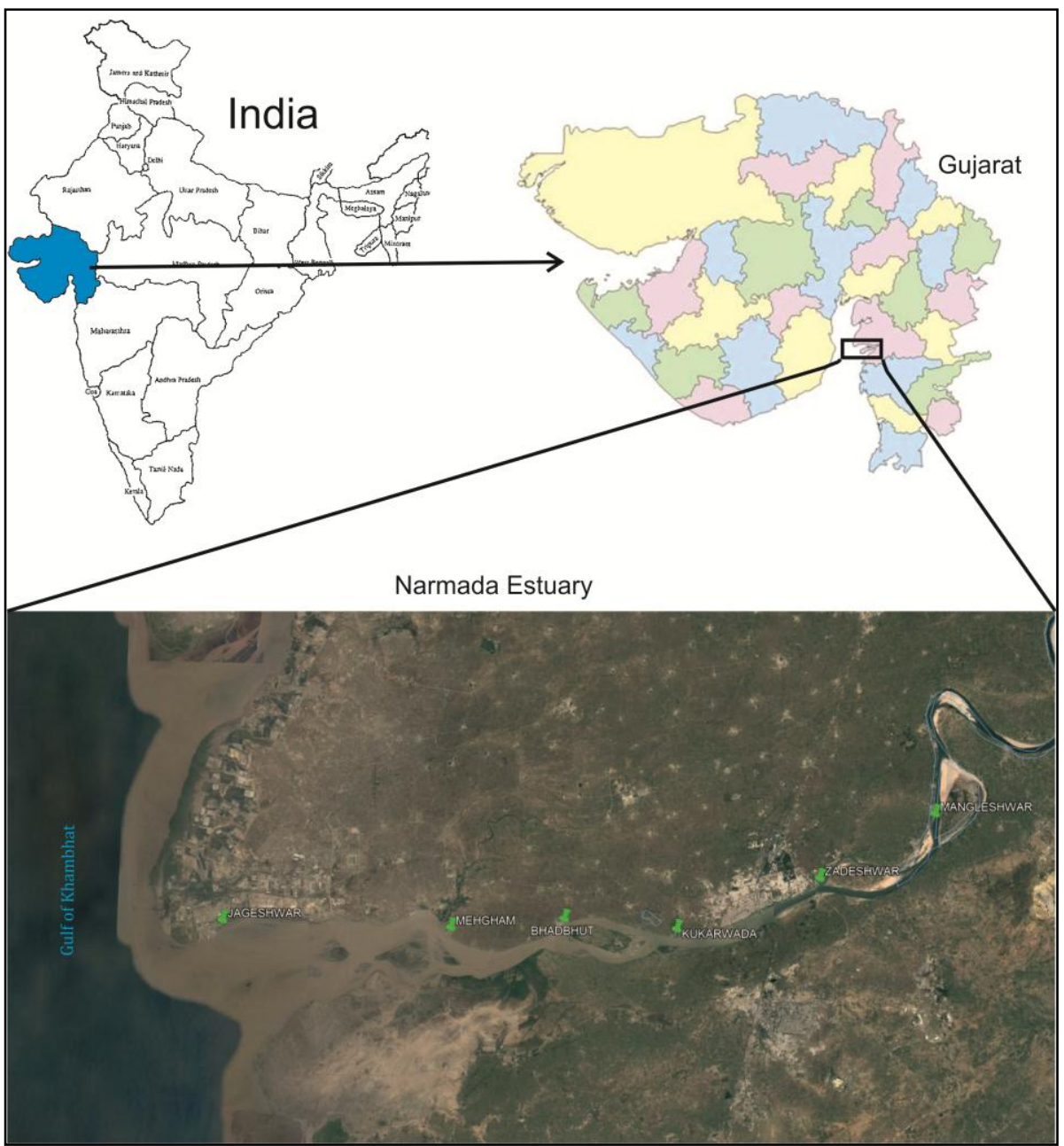

Fig.1:Sampling sites covering estuarine and riverine zone of the river Narmada, Gujarat State

Gujarat has the longest coast line (i.e. $1600 \mathrm{~km}$ ) among all the maritime states of India. It has two gulfs viz. Gulf of Kachchh and Gulf of Khambhat. There are 5 rivers that drain into the Gulf of Khambhat viz., Sabarmati, Mahi, Narmada, Tapi and Shetrunji. These rivers discharge large amount of the sediments in the Gulf of Khambhat [4]. The present study pertains to Narmada estuary and its adjoining river stretch only.

Narmada, a major river crossing Gujarat state, originates from Amarkantak hills in the Bilaspur district of Madhya Pradesh. The river is $1,312 \mathrm{~km}$ long and commands the total catchment area of $98,796 \mathrm{~km}^{2}$.It is surrounded by the Mandla hills, the Vindhya and Satpura ranges to the Gulf of Khambhat near Luhara [5].The river passes through Garudeshwar, Sinor, Nareshwar, Shukltirth, Bharuch, Kukurwada, Bhadbhut, Mehgam, Ambata and Luhara. The tidal influence extends at least up to Zanor, which is $75 \mathrm{~km}$ inland. The tidal range of about $5.5 \mathrm{~m}$ was recorded near the mouth which decreased to $1.7 \mathrm{~m}$ about 52 $\mathrm{km}$ upstream during the spring tide and upto $1.2 \mathrm{~m}$ during the neap tide [6].

\section{Methodology}

Stratified random sampling was used for in situ water quality assessment by selecting some sites with tidal influence (estuarine zone) and some other sites located beyond tidal influence (riverine zone). Water samples were collected from six selected sites for the time span of eight months ranging from February 2017 to September 2017. The samples were collected using grab sampling method during low tide and high tide both (Table 1) 
Table 1-Water sampling sites on Narmada river

\begin{tabular}{|c|c|c|c|c|}
\hline Site code & Village & Latitude (N) & Longitude (S) & Type of site \\
\hline NE1 & Mangleswer & $21^{\circ} 46^{\prime} 05.8^{\prime}$ & $73^{\circ} 08^{\prime} 05.8^{\prime \prime}$ & Riverine* \\
\hline NE2 & Zadeshwer & $21^{\circ} 43^{\prime} 06.5^{\prime}$ & $73^{\circ} 02^{\prime} 45.5^{\prime}$ & Riverine \\
\hline NE3 & Kukarwada & $21^{\circ} 40^{\prime} 39.4^{\prime \prime}$ & $72^{\circ} 56^{\prime} 06.0^{\prime \prime}$ & Estuarine* \\
\hline NE4 & Bhadbhut & $21^{\circ} 40^{\prime} 55.7^{\prime \prime}$ & $72^{\circ} 50^{\prime} 46.9^{\prime \prime}$ & Estuarine \\
\hline NE5 & Megham & $21^{\circ} 40^{\prime} 22.2^{\prime \prime}$ & $72^{\circ} 45^{\prime} 27.1^{\prime \prime}$ & Estuarine \\
\hline NE6 & Jageshwar & $21^{\circ} 40^{\prime} 19.8^{\prime \prime}$ & $72^{\circ} 34^{\prime} 40.2^{\prime \prime}$ & Estuarine \\
\hline
\end{tabular}

*Note: Estuarine and Riverine sites were demarcated based onpresence of tidal influence and absence of tidal influencerespectively.

The water samples were collected and analyzed as per "The Standard Methods" [7]. The samples were collected in 1 litre polyethylene bottles, stored in ice boxes at $-4^{\circ} \mathrm{C}$ and brought to the laboratory for analysis. A total of 11 physico-chemical parameters were analyzed that included 2 physical parameters (temperature and turbidity) and 9 chemical parameters. Measurements of $\mathrm{pH}$, water temperature, salinity, conductivity, dissolved oxygen, total dissolved solids and turbidity were carried out in situusing electronicprobes. The total investigation period of eight months categorized three seasons, was divided into three seasons i.e. Winter (February 2017) Summer (March 2017 to Mid-June 2017) and Monsoon (Mid-June 2017 to September 2017) for seasonal comparison.

\section{RESULTS AND DISCUSSION}

\section{Physical parameters}

\section{Water temperature}

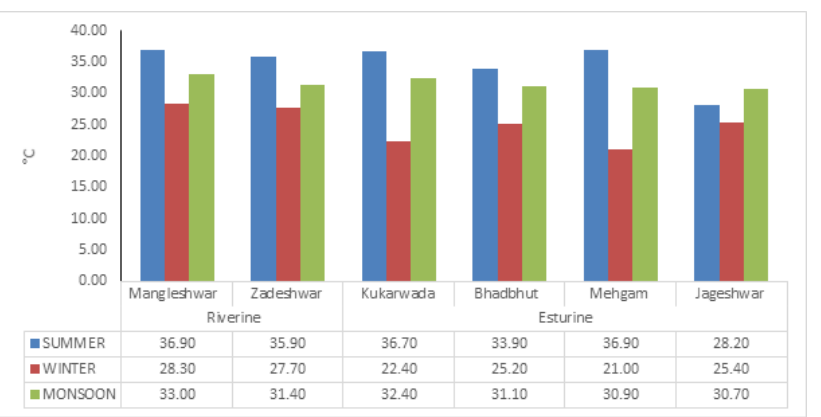

Fig. 2a: Seasonal water temperature variation at different estuarine and riverine sites on Narmada Riverduring high tide

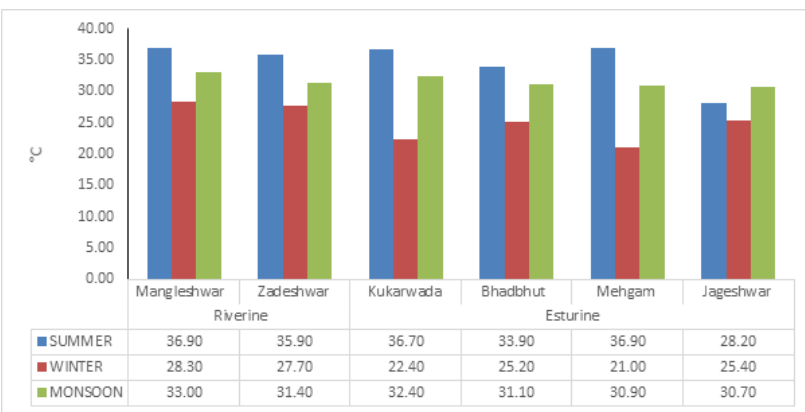

Fig. 2b: Seasonal water temperature variation at different estuarine and riverine sites on Narmada Riverduring high tide

During the study period (i.e. February 2017 to September 2017), water temperature at various estuarine and riverine sites was found to be ranging from $21.0^{\circ} \mathrm{C}$ to $36.90^{\circ} \mathrm{C}$. The highest water temperature (i.e. $36.90^{\circ} \mathrm{C}$ ) was recorded at Mehgam (an estuarine site) and Mangleshwar (a riverine site) during low tide in summer. On the other hand, lowest water temperature (i.e. $21.0^{\circ} \mathrm{C}$ ) was recorded at Mehgam (an estuarine site) in winter during low tide. Average value of water temperature for summer, winter and monsoon seasons during high tide was $31.32^{\circ} \mathrm{C}, 27.40^{\circ} \mathrm{C}$ and $30.52^{\circ} \mathrm{C}$ respectively. Thus, for the high tide conditions, water temperature was highest (i.e. $31.32^{\circ} \mathrm{C}$ ) in summer and the lowest (i.e. $27.40^{\circ} \mathrm{C}$ ) in winter. On the other hand, average value of water temperature recorded during low tide condition for summer, winter and monsoon was $34.75^{\circ} \mathrm{C}, 25.0^{\circ} \mathrm{C}$ and $31.58^{\circ} \mathrm{C}$ respectively. Thus, during the low tide condition water temperature was highest (i.e. $34.75^{\circ} \mathrm{C}$ ) in summer and the lowest (i.e. $25.0^{\circ} \mathrm{C}$ ) in winter.Water temperature plays a significant role for regulating the physico-chemical and biological characteristics of water. It is considered to be one of the most essential factors in the aquatic environment particularly for freshwater ecosystem [8]. Delince (1992) had found that the water temperature range of $30^{\circ} \mathrm{C}-35^{\circ} \mathrm{C}$ is tolerable to fish. 
Bhatnagar et al. (2004) had suggested that the temperature range of $28^{\circ} \mathrm{C}-32^{\circ} \mathrm{C}$ is good for tropical fishes (especially, major carps); temperature less than $20^{\circ} \mathrm{C}$ can be sub-lethal for many fishes and the temperature over $35^{\circ} \mathrm{C}$ lethal to maximum number of fish species. Santhosh and Singh (2007) have stated that water temperature between $24^{\circ} \mathrm{C}$ and $30^{\circ} \mathrm{C}$ is suitable for several fish.

\section{Turbidity}

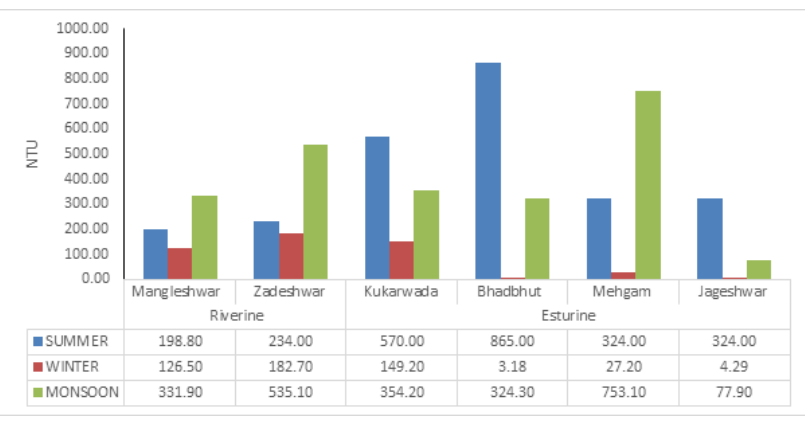

Fig. 3a: Seasonal turbidity variation at different sites on Narmada River (including estuary) during high tide

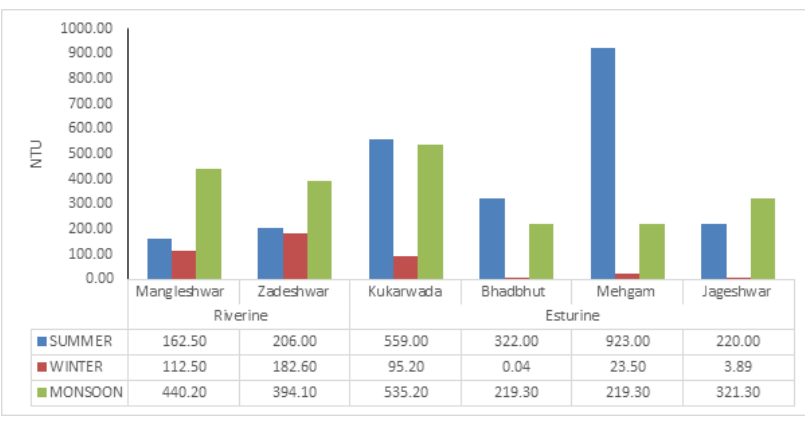

Fig. 3b: Seasonal turbidity variation at different sites on Narmada River (including estuary) during low tide

During the study period (i.e. fromFebruary 2017 to September 2017), turbidity at various estuarine and riverine sites was found to be ranging from 0.04 NTU to 923 NTU. The highest turbidity (i.e. 923 NTU) was recorded at Mehgam (an estuarine site)during low tide in summer. On the other hand, lowest turbidity (i.e. 0.04 NTU) was recorded at Bhadbhut (an estuarine site)in winter during low tide. Average value of turbidity for summer, winter and monsoon seasons during high tide was 419.30NTU, 82.18NTU and 396.08NTU respectively. Thus, for the high tide condition turbidity was highest (i.e. 419.30 NTU) in summer and the lowest (i.e. 82.18 NTU) in winter. On the other hand, average value of turbidity recorded during low tide condition for summer, winter and monsoon was $220.00 \mathrm{NTU}, 3.89 \mathrm{NTU}$ and $321.30 \mathrm{NTU}$ respectively. Thus, during low tide turbidity was highest (i.e. $321.30 \mathrm{NTU}$ ) in monsoon and the lowest (i.e. $3.89 \mathrm{NTU}$ ) in winter.

\section{Chemical parameters}

pH

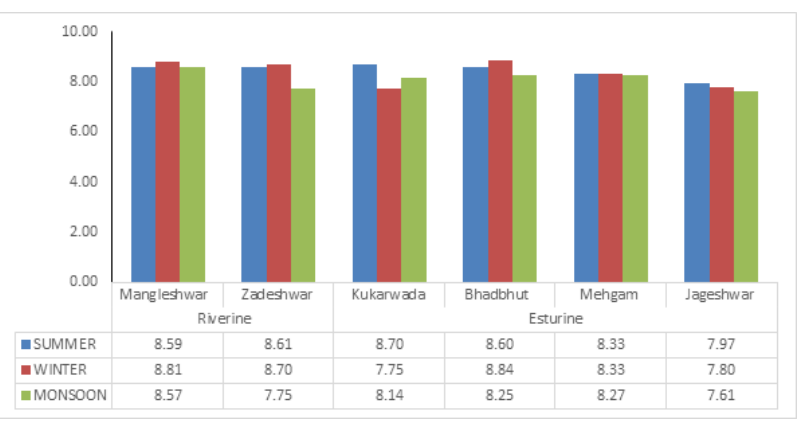

Fig. 4a: Seasonal $\mathrm{pH}$ variation at different estuarine and riverine sites on Narmada Riverduring high tide

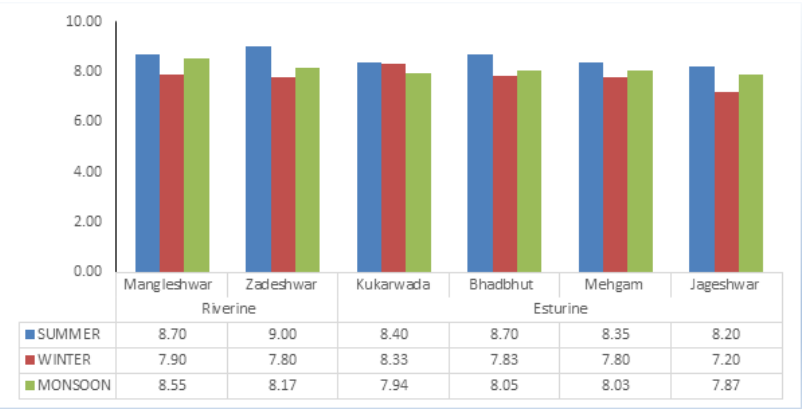

Fig. 4b: Seasonal $\mathrm{pH}$ variation at different estuarine and riverine sites on Narmada Riverduring low tide

During the study period (i.e February 2017 to September 2017), the $\mathrm{pH}$ at all the sampling sites varied only in alkaline range, i.e. 7.2 to 9.0. The highest $\mathrm{pH}$ (i.e. 9.0) was observed at Zadeshwar (a riverine site) during low tide in summer. On the other hand, lowest pH (i.e. 7.2) was observed at Jageshwar (an estuarine site) during low tide in winter. It might be noted that Zadeshwer is under tidal influence, whereas Jageshwar (an estuarine site) represents riverine conditions. Average value of $\mathrm{pH}$ recorded for summer, winter and monsoon was $8.47,8.37$ and 8.10 respectively during high tide. Thus, for the high tide 
conditions $\mathrm{pH}$ was highest (i.e. 8.47) in summer and the lowest (i.e. 8.10) in monsoon. On the other hand, average value of pH recorded during low tide condition for summer, winter and monsoon was 8.56, 7.81 and 8.10 respectively. Thus, for the low tide condition $\mathrm{pH}$ was highest (i.e. 8.56) in summer and lowest (i.e. 7.81) in winter. In other words, $\mathrm{pH}$ was found to remain at peak during summer season irrespective of tidal conditions. $\mathrm{pH}$ is important in evaluating the acid-base balance of water (Shukla, 1989).The suitable $\mathrm{pH}$ range for fish culture is between 6.7 and 9.5 and ideal $\mathrm{pH}$ level is between 7.5 and $8.5 \mathrm{pH}$ above and below these values is stressful to the fishes. Ideally for the wellbeing of fish should have a $\mathrm{pH}$ between 6.5 and 9.0 [9][10].

\section{Electrical Conductivity}

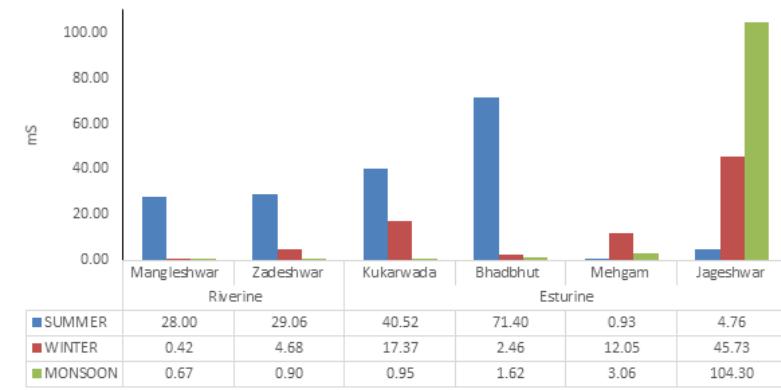

Fig. 5a: Seasonal electrical conductivity variation at different estuarine and riverine sites on Narmada Riverduring high tide

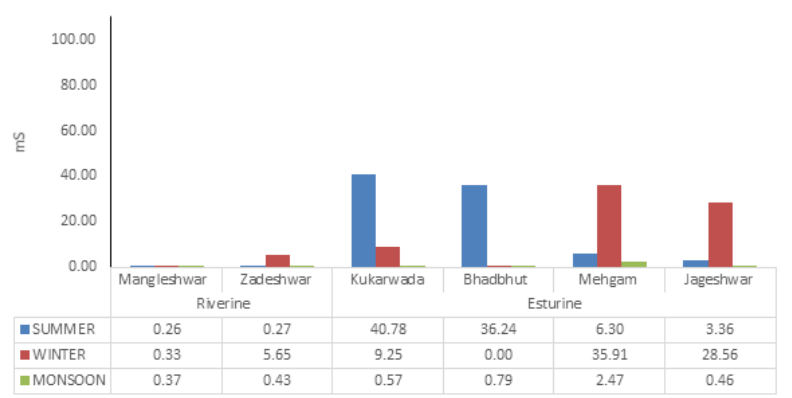

Fig. 5b: Seasonal electrical conductivity variation at different estuarine and riverine sites on Narmada Riverduring high tide

During the study period i.e. February 2017 to September 2017, Electrical Conductivity at various sites (estuarine and riverine) was found ranging from $0.0018 \mathrm{mS}$ to $40.78 \mathrm{mS}$. The highest EC (i.e. $40.78 \mathrm{mS}$ ) recorded at Kukerwada (an estuarine site) during low tide in summer. On the other hand, lowest EC (i.e. $0.0018 \mathrm{mS}$ ) was recorded at Bhadbhut (an estuarine site) in winter during low tide. Average value of EC recorded during high tide for summer, winter and monsoon was $29.11 \mathrm{mS}, 13.89$ $\mathrm{mS}$ and $18.58 \mathrm{mS}$ respectively. Thus, for the high tide condition EC was highest (i.e. 29.11 mS) in summer and the lowest (i.e. $13.89 \mathrm{mS}$ ) in winter. On the other hand, average value of EC recorded during low tide condition for summer, winter and monsoon was $14.54 \mathrm{mS}, 13.28 \mathrm{mS}$ and $0.85 \mathrm{mS}$ respectively. Thus, for the low tide condition EC was highest (i.e. $14.54 \mathrm{mS}$ ) in summer and the lowest (i.e. $0.85 \mathrm{mS}$ ) in monsoon. Electrical Conductivity measurement is an excellent indicator of TDS, which is a measure of salinity that affects the taste of potable water [10]

\section{Total Dissolved solids}

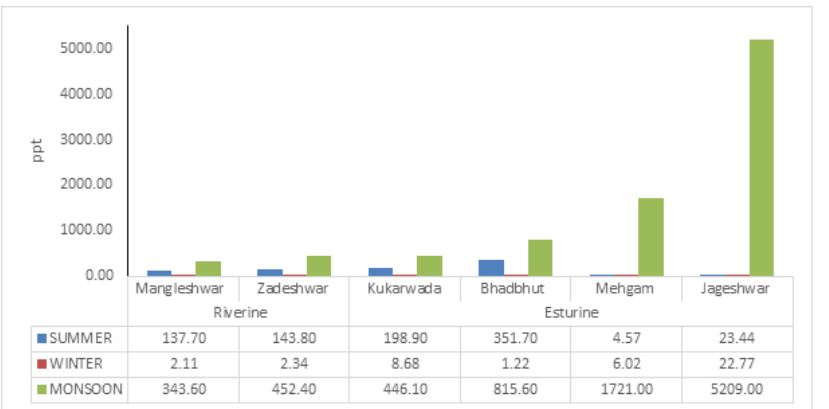

Fig. 6a: Seasonal total dissolved solids variation at different estuarine and riverine sites on Narmada Riverduring high tide

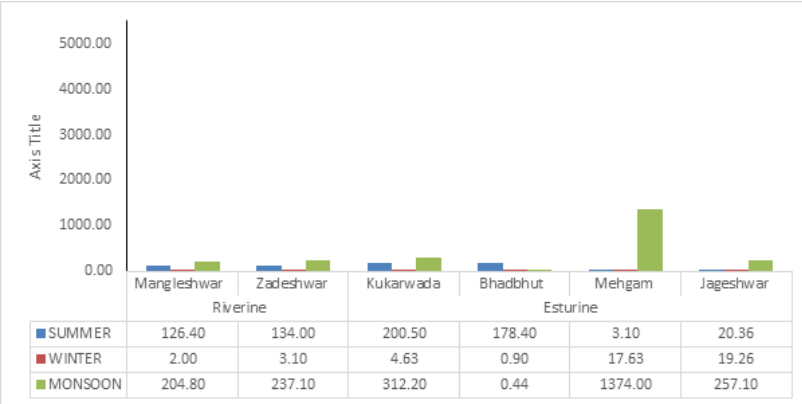

Fig. 6b: Seasonal total dissolved solids variation at different estuarine and riverine sites on Narmada Riverduring high tide

During the study period i.e. February 2017 to September 2017, Total Dissolved Solids at various sites (estuarine and riverine) was found ranging from $0.9 \mathrm{ppt}$ to $5209 \mathrm{ppt}$. The highest TDS (i.e. $5209 \mathrm{ppt}$ ) recorded at Jageshwar (an estuarine site) during high tide in monsoon. On the other hand, lowest TDS (i.e. 0.9 ppt) was recorded at Bhadbhut (an estuarine site) in winter during low tide. Average value of TDS recorded during high tide for summer, winter and monsoon was $193.35 \mathrm{ppt}, 7.19 \mathrm{ppt}$ 
and $1497.95 \mathrm{ppt}$ respectively. Thus, for the high tide condition TDS was highest (i.e. $1497.95 \mathrm{ppt}$ ) in monsoon and the lowest (i.e. $7.19 \mathrm{ppt}$ ) in winter. On the other hand, average value of TDS recorded during low tide condition for summer, winter and monsoon was $110.46 \mathrm{ppt}, 7.92 \mathrm{ppt}$ and $397.61 \mathrm{ppt}$ respectively. Thus, for the low tide condition TDS was highest (i.e. 397.61 ppt) in monsoon and the lowest (i.e. $7.92 \mathrm{ppt)}$ in winter. These values were slightly higher than the limit prescribed by ISI 10500-91. The higher TDS values could be attributed to the dissolution of soluble minerals present in clay deposits around this area TDS is a measure of the combined content of all inorganic and organic substances present in a liquid in molecular, ionized or micro-granular (colloidal sol) suspended form. It affects water quality in different ways. Generally, an excessive TDS level (greater than $1200 \mathrm{mg} / \mathrm{litre}$ ) in drinking-water is objectionable to consumers as it imparts a bad taste and may induce an unfavourable physiological reaction in the transient consumer and even may cause gastrointestinal irritation [11]. Water containing high solid concentration may cause constipation effects (Yadav and Singh 2014). High level of TDS may aesthetically be unsatisfactory for bathing and washing [12].

\section{Dissolved oxygen}

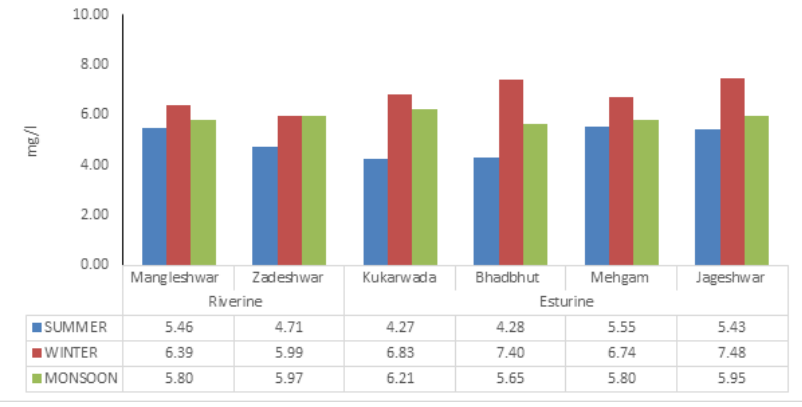

Fig. 7a: Seasonal dissolved oxygen variation at different estuarine and riverine sites on Narmada Riverduring high tide

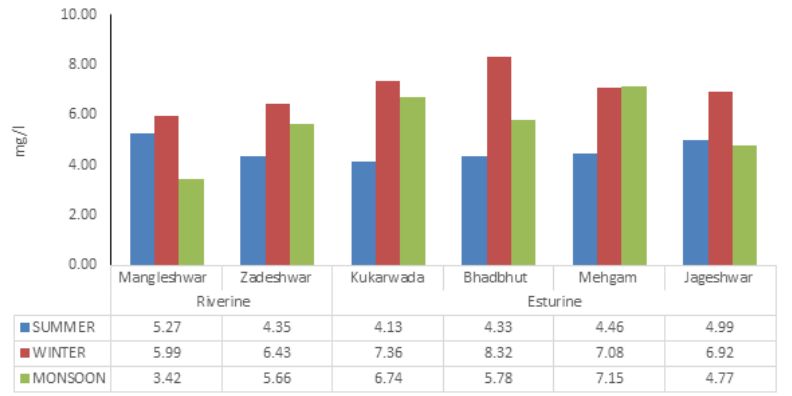

Fig. 7b: Seasonal dissolved oxygen variation at different estuarine and riverine sites on Narmada Riverduring high tide

During the study period i.e. February 2017 to September 2017, Dissolved Oxygen at various sites (estuarine and riverine) was found ranging from $3.42 \mathrm{mg} / \mathrm{l}$ to $8.32 \mathrm{mg} / \mathrm{l}$. The highest DO (i.e. $8.32 \mathrm{mg} / \mathrm{l}$ ) recorded at Bhadbhut (an estuarine site) during low tide in winter. On the other hand, lowest DO (i.e. $3.42 \mathrm{mg} / \mathrm{l}$ ) was recorded at Bhadbhut (an estuarine site) in monsoon during low tide. Average value of DO recorded during high tide for summer, winter and monsoon was $4.95 \mathrm{mg} / \mathrm{l}, 6.81 \mathrm{mg} / \mathrm{l}$ and 5.90 $\mathrm{mg} / \mathrm{l}$ respectively. Thus, for the high tide condition DO was highest (i.e. $6.81 \mathrm{mg} / \mathrm{l}$ ) in winter and the lowest (i.e. $4.95 \mathrm{mg} / \mathrm{l}$ ) in summer. On the other hand, average value of DO recorded during low tide condition for summer, winter and monsoon was $4.59 \mathrm{mg} / \mathrm{l}, 7.02 \mathrm{mg} / \mathrm{l}$ and $5.59 \mathrm{mg} / \mathrm{l}$ respectively. Thus, for the low tide condition DO was highest (i.e. $7.02 \mathrm{mg} / \mathrm{l})$ in winter and the lowest (i.e. $4.59 \mathrm{mg} / \mathrm{l}$ ) in summer. In the progress of summer, dissolved oxygen decreased due to increase in temperature and also due to increased microbial activity. DO is one of the most important parameter. Its correlation with water body gives direct and indirect information e.g. bacterial activity, photosynthesis, availability of nutrients, stratification etc.

\section{Salinity}

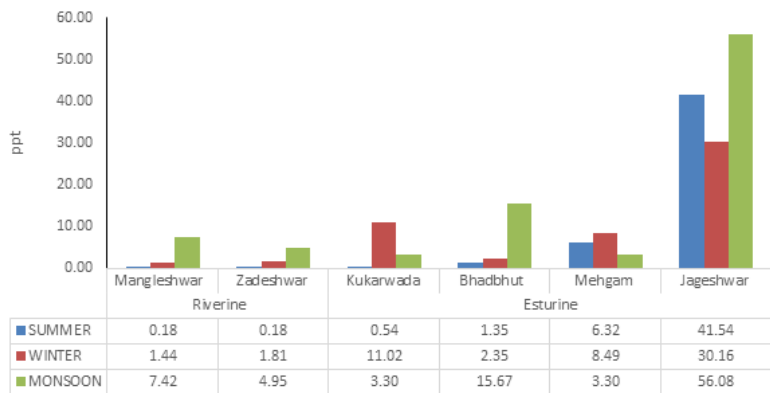

Fig. 8a: Seasonal salinity variation at different estuarine and riverine sites on Narmada Riverduring high tide

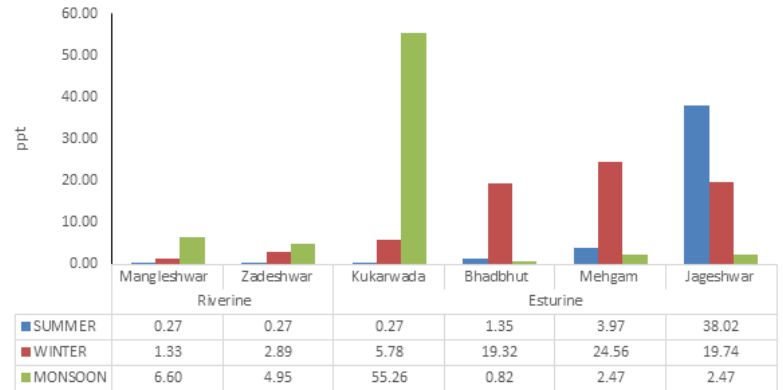

Fig. 8b: Seasonal salinity variation at different estuarine and riverine sites on Narmada Riverduring low tide 
During the study period i.e. February 2017 to September 2017, Salinity at various sites (estuarine and riverine) was found ranging from $0.27 \mathrm{ppt}$ to $56.08 \mathrm{ppt}$. The highest salinity (i.e. $56.08 \mathrm{ppt}$ ) recorded at Jageshwar (an estuarine site) during high tide in monsoon. On the other hand, lowest salinity (i.e. $0.27 \mathrm{ppt}$ ) was recorded at Kukarwada (an estuarine site), Mangleshwer (an estuarine site) and Zadeshwer (a riverine site) in summer during low tide. Average value of salinity recorded during high tide for summer, winter and monsoon was $8.35 \mathrm{ppt}, 9.21 \mathrm{ppt}$ and $15.12 \mathrm{ppt}$ respectively. Thus, for the high tide condition salinity was highest (i.e. $15.12 \mathrm{ppt}$ ) in monsoon and the lowest (i.e. $8.35 \mathrm{ppt}$ ) in summer. On the other hand, average value of salinity recorded during low tide condition for summer, winter and monsoon was $7.36 \mathrm{ppt}, 12.27 \mathrm{ppt}$ and $12.10 \mathrm{ppt}$ respectively. Thus, for the low tide condition salinity was highest (i.e. $12.27 \mathrm{ppt}$ ) in winter and the lowest (i.e. $7.36 \mathrm{ppt}$ ) in summer. Salinity explains the percentage of chloride in water. Normally sea water contains $35 \mathrm{~g} / \mathrm{l}$ of chlorides and freshwater contains up to $5 \mathrm{~g} / \mathrm{l}$.

\section{Acidity}
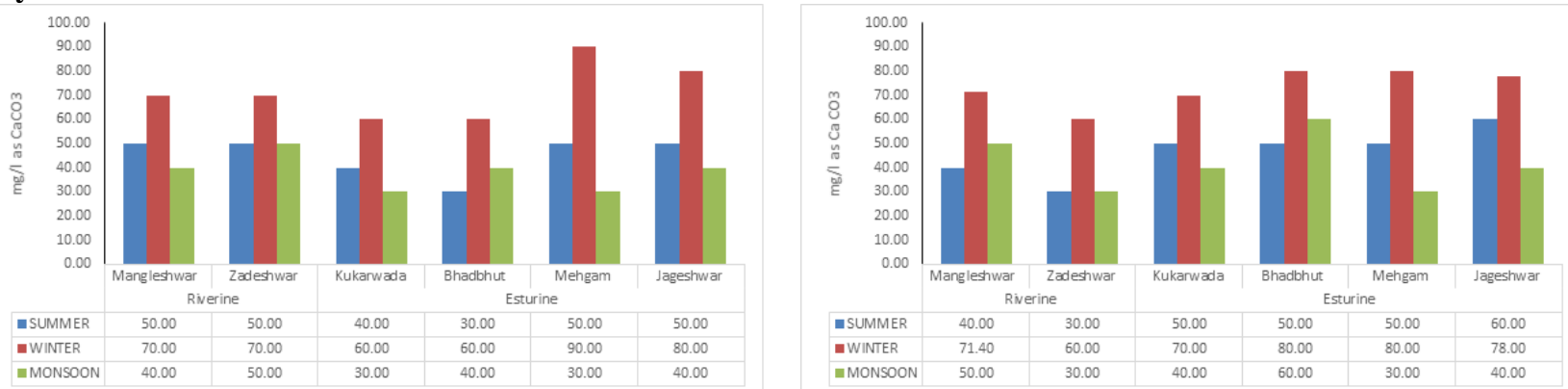

Fig. 9a: Seasonal acidity variation at different estuarine and riverine sites on Narmada Riverduring high tide

Fig. 9b: Seasonal acidity variation at different estuarine and riverine sites on Narmada Riverduring low tide

During the study period i.e. February 2017 to September 2017, Acidity at various sites (estuarine and riverine) was found ranging from $30 \mathrm{mg} / \mathrm{l}$ as $\mathrm{CaCO}_{3}$ to $90 \mathrm{mg} / \mathrm{l}$ as $\mathrm{CaCO}_{3}$. The highest Acidity (i.e. $90 \mathrm{mg} / \mathrm{l}$ as $\mathrm{CaCO}_{3}$ ) recorded at Megham (an estuarine site) during high tide in winter. On the other hand, lowest Acidity (i.e. 30mg/l as $\mathrm{CaCO}_{3}$ ) was recorded at Megham (an estuarine site) and Zadeshwar (a riverine site) in summer during high tide. Average value of Acidity recorded during high tide for summer, winter and monsoon was $45.00 \mathrm{mg} / 1$ as $\mathrm{CaCO}_{3}, 71.67 \mathrm{mg} / 1$ as $\mathrm{CaCO}_{3}$ and $38.33 \mathrm{mg} / 1$ as $\mathrm{CaCO}_{3}$ respectively. Thus, for the high tide condition Acidity was highest (i.e. $71.67 \mathrm{mg} / \mathrm{l}$ as $\mathrm{CaCO}_{3}$ ) in winter and the lowest (i.e. $38.33 \mathrm{mg} / \mathrm{l}$ as $\mathrm{CaCO}_{3}$ ) in monsoon. On the other hand, average value of Acidity recorded during low tide condition for summer, winter and monsoon was $46.67 \mathrm{mg} / \mathrm{l}$ as $\mathrm{CaCO}_{3}, 73.23 \mathrm{mg} / \mathrm{l}$ as $\mathrm{CaCO}_{3}$ and $41.67 \mathrm{mg} / 1$ as $\mathrm{CaCO}_{3}$ respectively. Thus, for the low tide condition Acidity was highest (i.e. $73.23 \mathrm{mg} / \mathrm{l}$ as $\mathrm{CaCO}_{3}$ ) in winter and the lowest (i.e. $41.67 \mathrm{mg} / \mathrm{l}$ as $\mathrm{CaCO}_{3}$ ) in monsoon.

\section{Alkalinity}

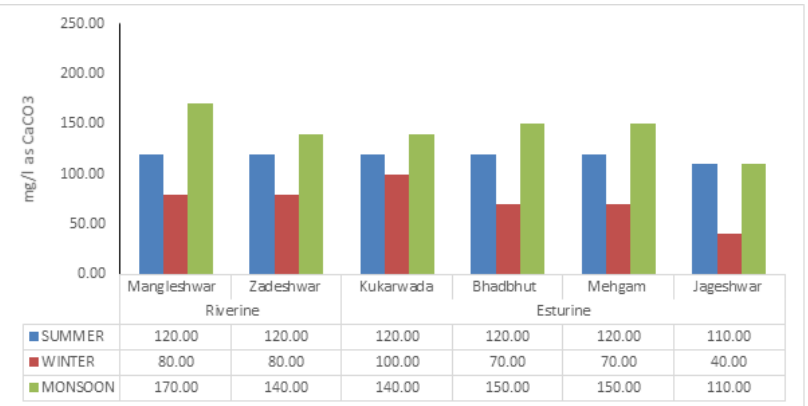

Fig. 10a: Seasonal alkalinity variation at different estuarine and riverine sites on Narmada during high tide

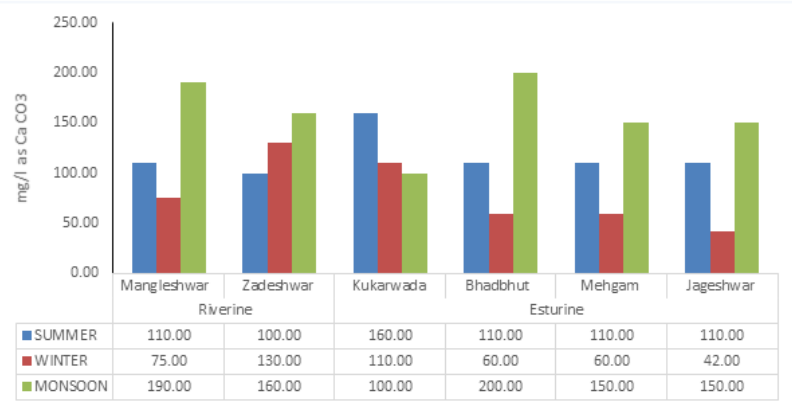

Fig. 10b: Seasonal alkalinity variation at different estuarine and riverine sites on Narmada Riverduring low tide

During the study period, Alkalinity at various estuarine and riverine sites ranged from $40 \mathrm{mg} / \mathrm{l}$ as $\mathrm{CaCO}_{3}$ to $200 \mathrm{mg} / \mathrm{l}$ as $\mathrm{CaCO}_{3}$. The highest alkalinity (i.e. $40 \mathrm{mg} / \mathrm{l}$ as $\mathrm{CaCO}_{3}$ ) recorded at Jageshwar (an estuarine site) during low tide in winter. On the other hand, lowest alkalinity (i.e. $200 \mathrm{mg} / \mathrm{l}$ as $\mathrm{CaCO}_{3}$ ) was recorded at Bhadbhut (an estuarine site) in monsoon during high tide. Average value of alkalinity recorded during high tide for summer, winter and monsoon was $118.33 \mathrm{mg} / \mathrm{l}$ as $\mathrm{CaCO}_{3}, 73.33 \mathrm{mg} / \mathrm{l}$ 
as $\mathrm{CaCO}_{3}$ and $143.33 \mathrm{mg} / \mathrm{l}$ as $\mathrm{CaCO}_{3}$ respectively. Thus, for the high tide condition alkalinity was highest (i.e. $143.33 \mathrm{mg} / \mathrm{l}$ as $\mathrm{CaCO}_{3}$ ) in monsoon and the lowest (i.e. $73.33 \mathrm{mg} / \mathrm{l}$ as $\mathrm{CaCO}_{3}$ ) in winter. On the other hand, average value of alkalinity recorded during low tide condition for summer, winter and monsoon was $116.67 \mathrm{mg} / \mathrm{l}$ as $\mathrm{CaCO}_{3}, 79.50 \mathrm{mg} / \mathrm{l}$ as $\mathrm{CaCO}_{3}$ and $158.33 \mathrm{mg} / \mathrm{l}$ as $\mathrm{CaCO}_{3}$ respectively. Thus, for the low tide condition alkalinity was highest (i.e. $158.33 \mathrm{mg} / \mathrm{l}$ as $\mathrm{CaCO}_{3}$ ) in monsoon and the lowest (i.e. $79.50 \mathrm{mg} / \mathrm{l}$ as $\mathrm{CaCO}_{3}$ ) in winter. Alkalinity value of water provides an estimate of dissolved mineral salts. Little abnormal value of alkalinity is not harmful to human beings [13] but it is important to determine the suitability of water for irrigation and/or mixing some pesticides.

\section{Total Hardness}

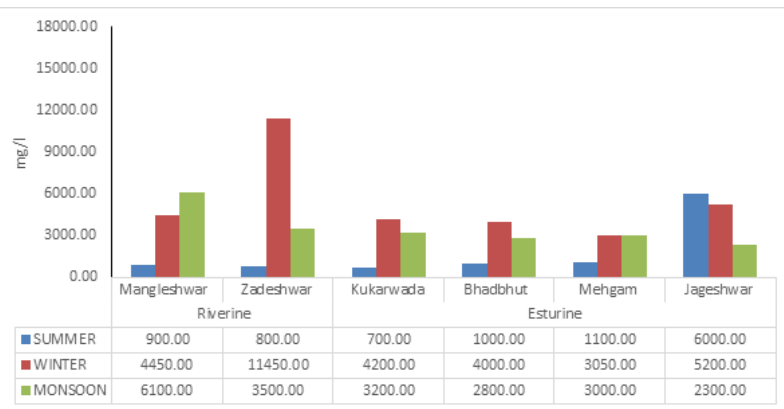

Fig. 11a: Seasonal Total hardness variation at different estuarine and riverine sites on Narmada Riverduring high tide

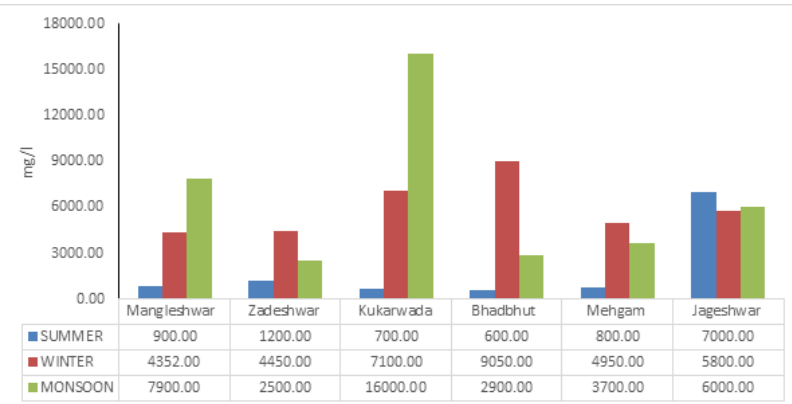

Fig. 11b: Seasonal Total hardness variation at different estuarine and riverine sites on Narmada Riverduring low tide

Total Hardness of water is mainly due to the presence of calcium and magnesium ions, and it is an important indicator of the toxic effect of poisonous elements [14]. From February 2017 to September 2017, Total Hardness at various estuarine and riverine sites was found to be ranging from $600 \mathrm{mg} / \mathrm{l}$ as $\mathrm{CaCO}_{3}$ to $16000 \mathrm{mg} / \mathrm{l}$ as $\mathrm{CaCO}_{3}$. The highest Total Hardness (i.e. $16000 \mathrm{mg} / \mathrm{l}$ as $\mathrm{CaCO}_{3}$ ) was recorded at Kukarwada (an estuarine site) during low tide in monsoon. On the other hand, lowest Total Hardness (i.e. $600 \mathrm{mg} / \mathrm{l}$ as $\mathrm{CaCO}_{3}$ ) was recorded at Bhadbhut (an estuarine site) in summer during low tide. Average value of Total Hardness recorded during high tide for summer, winter and monsoon was $1750.00 \mathrm{mg} / \mathrm{l}$ as $\mathrm{CaCO}_{3}, 5391.67 \mathrm{mg} / \mathrm{l}$ as $\mathrm{CaCO}_{3}$ and $3483.33 \mathrm{mg} / \mathrm{l}$ as $\mathrm{CaCO}_{3}$ respectively. Thus, for the high tide condition Total Hardness was highest (i.e. 5391.67 $\mathrm{mg} / \mathrm{l}$ as $\mathrm{CaCO}_{3}$ ) in winter and the lowest (i.e. $1750.00 \mathrm{mg} / \mathrm{l}$ as $\mathrm{CaCO}_{3}$ ) in summer. On the other hand, average value of Total Hardness for summer, winter and monsoon during low tide condition was $1866.67 \mathrm{mg} / \mathrm{l}$ as $\mathrm{CaCO}_{3}, 5950.33 \mathrm{mg} / \mathrm{l}$ as $\mathrm{CaCO}_{3}$ and $6500.00 \mathrm{mg} / \mathrm{l}$ as $\mathrm{CaCO}_{3}$ respectively. Thus, for the low tide condition Total Hardness was highest (i.e. $6500.00 \mathrm{mg} / \mathrm{l}$ as $\mathrm{CaCO}_{3}$ ) in monsoon and the lowest (i.e. $1866.67 \mathrm{mg} / \mathrm{l}$ as $\mathrm{CaCO}_{3}$ ) in summer. Total Hardness is an important parameter of water quality from the view point of the use of water for domestic, industrial or agricultural purposes. Hardness of water is undesirable considering that it prevents the lather formation with soap, increases the boiling point of water and can lead to the formation of kidney stones and heart disease [15].

\section{CONCLUSION AND RECOMMENDATION}

It is revealed from the present study that the water quality of selected sites at river Narmada estuary is fairly good. However, some parameters such as Total Hardness, Turbidity and Total Dissolved Solids at few estuarine sites (viz. Kukarwada, Bhadbhut, Megham, Jageshwer) were above the values of the maximum permissible limit for domestic water quality as per IS 10500 - 2004. The major source of pollutants at these sites includes anthropogenic activities, agricultural run-off and discharge of industrial effluent. Therefore, it is recommended that the effluents from industries and domestic sewage must be given proper primary and secondary treatments before releasing it into the river Narmada and its estuary at Gulf of Khambhat.

\section{ACKNOWLEDGEMENTS}

Authors are thankful to Forests and Environmental Department, Gujarat state for sponsoring this study. Authors also thank to Laboratory Staff Mr. Jamin Mali and Ms. Vaishali Parmar. Thanks are also due to Mr. Vikram Singh, Project Manager and Dr. Vijay Mackwana, Laboratory Superintendent of GEER Foundation. 


\section{REFERENCES}

[1]. Prandle D. (2009) Estuaries: dynamics, mixing, sedimentation and morphology. Cambridge University Press

[2]. McHugh J.L. (1967). Estuarine nekton. In: Estuaries. G. H. Lauff (ed.). Vol. 83. Am. Assoc. Adv. Sci., Spec. Publ., Washington, DC. 581-619.

[3]. Costanza R., d'Arge R., De Groot R., Farber S., Grasso M., Hannon B. and Raskin, R. G. (1997) The value of the world's ecosystem services and natural capital. nature, 387(6630), 253

[4]. Deshkar S., Lakhmapurkar J. and Gaval D. (2012) State of three estuary of Gulf of Khmbhat. Indian journal of Geo - Marine Science Vol 41 (1) 70-75

[5]. Gazetteer of Hoshangabad (1979) Govt. of India, Madhya Pradesh

[6]. George B., Kumar J. N. and Kumar R. N. (2012) Study on the influence of hydro-chemical parameters on phytoplankton distribution along Tapi estuarine area of Gulf of Khambhat, India. The Egyptian Journal of Aquatic Research, 38(3), 157-170.

[7]. APHA (2005) Standard methods for the examination of water and waste water, 21st edn. American Public Health Association, Washington DC

[8]. Singh R.P. and Mathur P. (2005) Investigation of variations in physicochemical characteristics of a fresh water reservoir of Ajmer city, Rajasthan. Indian JournalEnvironmental Sciences, 9, 57-61.

[9]. Wurts W.A. and Durborow R. M., (1992) Interactions of pH, Carbon Dioxide, Alkalinity and Hardness in Fish Ponds Southern Regional Aquaculture Center, SRAC Publication No. 464

[10]. Unnisa S.A. and Khalilullah M., (2004) Impact of industrial pollution on ground and surface water quality in the Kattedan industrial area, $J$. of Indian Association for Enviro. Management, 31, 77-80

[11]. Adak M.G., and Purohit K.M. (2001) Poll. Res., Chemical properties of drinking water of some villages in sangamner tahasil, DistAhmednagar, Maharashtra, India and its Impact on Human Health 20:575

[12]. Jameel A.A. and Sirajudeen J. (2006) Risk assessment of physicochemical contaminants in groundwater of pettavaithalai area, Tiruchirappalli, Tamilnadu - India. Environ Monit Assess 123:299-312. doi:http://dx.doi.org/10.1007/s10661-006-9198-5

[13]. Ahmad Ansari A.H.M., Sayeed S.M. and Khan A.F. (2008) Proc actors controlling detrital mineralogy of the sandstone of the lameta formation (Cretaceous), Jabalpur Area, Madhya Pradesh, India. Indian Natl Sci Acad 74(2):51-56

[14]. Tiwari D.R. (2001) Hydro geochemistry of underground water in and around Chatarpur city. Indian Environ Health, $43(4), 176$.

[15]. Sastry K.V., Rathee P. (1988) Physico- chemical and microbiological characteristics of water of village Kanneli (Dist. Rohtak) Haryana. Proc Acad Environ Biol 7(1): 103-108

\section{Author's Profile}

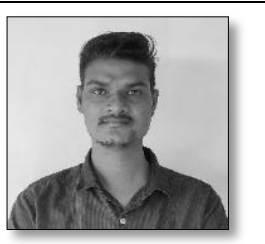

Ronak Gupta is a Junior Research Fellow at Gujarat Ecological Education and Research (GEER) Foundation, Gandhinagar, Gujarat, India. He has completed his Masters in Environmental Science from Kadi Sarva Vishvavidhyalaya University, Kadi. He has done research in the field environment pertaining to analyses of Water, Sediments and Plankton. He also has laboratory work experience and contributed in development of the subject through his knowledge of field and laboratory.

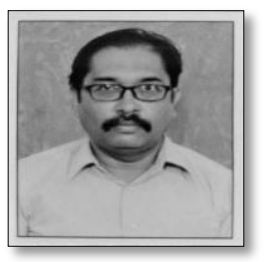

Dr. Ketan Tatu is the Senior Scientist, Gujarat Ecological Education and Research (GEER) Foundation, Gandhinagar. He has earned a Ph.D. in Environment Science from Gujarat University, India and a Ph.D. in Forest Resources Science, West Virginia University, USA. He is a Member of State Wetland Authority of Gujarat State and a Member of SACON Society. Dr. Tatu is the Founding Editor of "Jalaplavit" (ISSN 2321-1881)- an ePeriodical to enhance the knowledge about wetland biodiversity among people and sensitize them for its conservation. He is also a writer of an on-going column "Lap of Nature" in a newspaper "Daily News \& Analysis" (DNA) that is aimed at inculcating interest in Nature and appreciation for it among laymen. He has authored/coauthored many scientific papers, Technical Reports, books and book chapters in the field of wetlands and birds. Dr. KetanTatu is a Life Member of Bombay Natural History Society (BNHS) and Bird Conservation Society, Gujarat (BCSG).

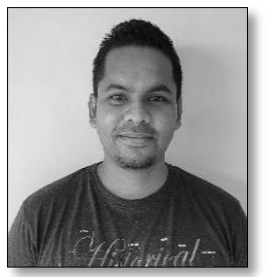

Lamb Christian is a Junior Research Fellow at Gujarat Ecological Education and Research (GEER) Foundation, Gandhinagar, Gujarat, India. He has completed his Masters in Environmental Science from Gujarat University, India. He has done research in the field environment with special emphasis to analyses of Water, Sediments and Plankton. He also has laboratory work experience and contributed in development of the subject through his knowledge of field and laboratory. 


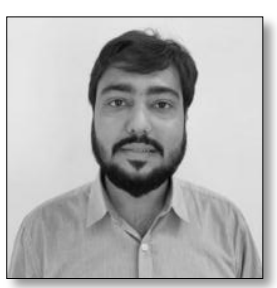

Darpak Joshi is a Junior Reseach Fellow at Gujarat Ecological Education and Research (GEER) Foundation, Gandhinagar, Gujarat, India. He has completed his Masters in Zoology from Gujarat University, India. He has done research in the field of wildlife science with emphasis on birds and mammals in freshwater wetland dominated Protected Areas. He has been contributing to environmental education and awareness programme through radio talks and Nature Education camps.

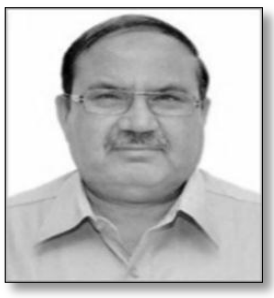

Mr. R. D. Kamboj is an Indian Forest Services Officer of Gujarat cadre (1986 batch) of the rank of Additional Principal Chief Conservator of Forests. He holds post graduate degree in Agriculture from Haryana Agriculture University, Hisar\& in Forestry from Indira Gandhi National Forest Academy, Dehradun. He has served in various positions in Gujarat Forest Department for last 32 years. He has published more than 60 research papers and has written Working Plans/ Management Plans for various forest divisions including Gir National Park \& Sanctuary. Presently he is serving as Director, Gujarat Ecological Education and Research (GEER) Foundation, Gandhinagar. 